\title{
Anti-C2 Antibody ARGX-117 Inhibits Complement in a Disease Model for Multifocal Motor Neuropathy
}

Kevin Budding, PhD, * Lill Eva Johansen, MSc, * Inge Van de Walle, PhD, Kim Dijkxhoorn, BSc, Elisabeth de Zeeuw, MSc, Lauri M. Bloemenkamp, BSc, Jeroen W. Bos, MD, Marc D. Jansen, BSc, Chantall A.D. Curial, BSc, Karen Silence, PhD, Hans de Haard, PhD, Christophe Blanchetot, PhD, Liesbeth Van de Ven, MSc, Jeanette H.W. Leusen, PhD, R. Jeroen Pasterkamp, PhD, Leonard H. van den Berg, MD, PhD, C. Erik Hack, MD, PhD, Peter Boross, PhD, * and W. Ludo van der Pol, MD, PhD*

Neurol Neuroimmunol Neuroinflamm 2022;9:e1107. doi:10.1212/NXI.0000000000001107

\section{Abstract}

\section{Background and Objectives}

To determine the role of complement in the disease pathology of multifocal motor neuropathy (MMN), we investigated complement activation, and inhibition, on binding of MMN patientderived immunoglobulin $\mathrm{M}$ (IgM) antibodies in an induced pluripotent stem cell (iPSC)derived motor neuron $(\mathrm{MN})$ model for MMN.

\section{Methods}

iPSC-derived MNs were characterized for the expression of complement receptors and membrane-bound regulators, for the binding of circulating IgM anti-GM1 from patients with $\mathrm{MMN}$, and for subsequent fixation of $\mathrm{C} 4$ and $\mathrm{C} 3$ on incubation with fresh serum. The potency of ARGX-117, a novel inhibitory monoclonal antibody targeting C2, to inhibit fixation of complement was assessed.

\section{Results}

iPSC-derived MNs moderately express the complement regulatory proteins CD46 and CD55 and strongly expressed CD59. Furthermore, MNs express C3aR, C5aR, and complement receptor 1. IgM anti-GM1 antibodies in serum from patients with MMN bind to MNs and induce $\mathrm{C} 3$ and $\mathrm{C} 4$ fixation on incubation with fresh serum. ARGX-117 inhibits complement activation downstream of $\mathrm{C} 4$ induced by patient-derived anti-GM1 antibodies bound to MNs.

\section{Discussion}

Binding of IgM antibodies from patients with MMN to iPSC-derived MNs induces complement activation. By expressing complement regulatory proteins, particularly CD59, MNs are protected against complement-mediated lysis. Yet, because of expressing $\mathrm{C} 3 \mathrm{aR}$, the function of these cells may be affected by complement activation upstream of membrane attack complex formation. ARGX-117 inhibits complement activation upstream of $\mathrm{C} 3$ in this disease model for MMN and therefore represents an intervention strategy to prevent harmful effects of complement in MMN.

\footnotetext{
*These authors contributed equally to this work (co-first authors and co-senior authors).

From the Center for Translational Immunology (K.B., K.D., E.Z., L.M.B., J.H.W.L., C.E.H., P.B.), University Medical Center Utrecht; Department of Neurology and Neurosurgery (L.E.J., L.M.B., J.W.B., M.D.J., C.A.D.C., L.H.B., W.L.P.), University Medical Center Utrecht Brain Center; Department of Translational Neuroscience (L.E.J., L.M.B., R.J.P.), University Medical Center Utrecht Brain Center, Utrecht University; Argenx BVBA, Industriepark-Zwijnaarde 7 (I.W., K.S., H.H., C.B., L.V.), Zwijnaarde, Belgium; and Prothix (C.E.H., P.B.), Leiden, the Netherlands. 


\section{Glossary}

DAPI = 4'6-diamidino-2-phenylindole; EDTA = ethylenediamine tetraacetic acid; FACS = fluorescent-activated cell sorting; IgM = immunoglobulin M; iPSC = induced pluripotent stem cell; IVIg = IV immunoglobulin; MAC = membrane attack complex; $\mathbf{M M N}$ = multifocal motor neuropathy; $\mathbf{M N}$ = motor neuron; $\mathbf{R T}=$ room temperature; $\mathbf{S C}=$ Schwann cell.

Multifocal motor neuropathy (MMN) is a rare chronic, presumably inflammatory, pure motor polyneuropathy leading to slowly progressive muscle weakness, mainly of the hands and forearms and lower legs. ${ }^{1,2}$ Specific pathophysiologic characteristics of $\mathrm{MMN}$ include the presence of immunoglobulin $\mathrm{M}(\mathrm{IgM})$ autoantibodies against the ganglioside GM1 and conduction block, i.e., impaired propagation of action potentials along the axon. GM1 is widely expressed in the nervous system by neurons, particularly around the nodes of Ranvier, and Schwann cells (SCs). ${ }^{3-5}$ Whether MMN is primarily a demyelinating or axonal neuropathy has been debated. Initial reports included the presence of demyelination and axonal degeneration in damaged nerves, but the number of pathologic studies is limited, and their results are inconsistent. The prevailing view is currently that GM1 antibodies target the axolemma at nodes of Ranvier. This is thought to interfere with axon-Schwann cell interactions, causing widening of the node and axonal damage. ${ }^{1,2,6}$ Presence and titers of IgM anti-GM1 antibodies, as well as their complement activating properties, correlate with clinical features such as weakness and axonal damage. ${ }^{7}$ Moreover, the binding of anti-GM1 IgM from patients to motor neurons ( $\mathrm{MNs}$ ) derived from induced pluripotent stem cells (iPSCs) and subsequent activation of the classical complement pathway causes disturbed calcium homeostasis and structural damage of these cells in vitro resembling changes occurring in $\mathrm{MMN}{ }^{8}$ These findings suggest a central role of IgM anti-GM1 and complement targeting to motor axons in the etiology of MMN.

High-dose IV immunoglobulin (IVIg) treatment is the only approved treatment for MMN, with subcutaneous Ig as an alternative. $^{9,10}$ This treatment often improves muscle strength - but needs to be repeated regularly in the short term - and is less effective at preventing progression of axonal loss in the long term. ${ }^{1,11}$ The immunomodulatory effects of high-dose IVIg include the inhibition of the classical pathway of the complement system, which is the main effector mechanism of IgM antibodies. ${ }^{12}$ Therefore, it can be postulated that IgM anti-GM1 antibodies bound to the axolemma disturb the function of MNs by classical pathway activation and the subsequent formation of $\mathrm{C} 3$ and $\mathrm{C} 5$ convertases and formation of the membrane attack complex (MAC). ${ }^{13}$

We hypothesize that targeting the classical complement pathway is a potential therapeutic approach in MMN. We investigated the interaction of circulating anti-GM1 IgM from patients with MMN with complement in detail using iPSCderived MNs. In this disease model for MMN, we evaluated the effects of ARGX-117, a novel monoclonal antibody that inhibits complement factor $\mathrm{C} 2$.

\section{Methods}

\section{Standard Protocol Approvals, Registrations, and Patient Consents}

This study was approved by the Medical Ethical Committee of the UMC Utrecht for both the generation of iPSC-derived MNs (METC protocol nr: NL39918.041.12) and the collection of MMN patient material (METC protocol nr: 14528). Written informed consent was obtained from all participants.

\section{Patients and Controls}

Blood samples were obtained from patients who met the diagnostic consensus criteria for $\mathrm{MMN}^{14}$ (eTable 1, links.lww. com/NXI/A652). All patients received IVIg therapy at sampling. Routine clinical evaluation of patients with MMN includes measurement of circulating IgM antibodies against GM1 with ELISA. ${ }^{15}$ Titers of anti-GM1 antibodies used for the present study were obtained from the clinical records. In case this titer had not been measured at the same day as the blood sample used for the present study had been collected, the titer determined at the most nearby time point was used. Blood samples from healthy volunteers were collected via the in-house donor facility of the UMC Utrecht. Serum samples were heat inactivated $\left(30\right.$ minutes $\left.56^{\circ} \mathrm{C}\right)$ and stored in aliquots at $-80^{\circ} \mathrm{C}$ until used.

\section{Antibodies and Reagents}

ARGX-117 is a humanized, Fc-engineered human IgG1 inhibitory anti-C2 antibody in development by argenx. Its characterization is described elsewhere. ${ }^{16}$ The commercial antibodies used are given in the online supplement. Other reagents were cholera toxin B subunit-AF488 (Thermo Fisher, \#C34775, 1: 500 ), complement-active human pooled serum (Innovative Research), complement-active C2-depleted serum (Complement Technology), purified human serum C2 (Complement Technology), EDTA (Riedel de Haen), MgEGTA (Complement Technology), and veronal buffered saline, $\mathrm{pH} 7.4$ (VB, Lonza).

\section{iPSC-Derived MNs and sNF96.2 Cell Line}

Human iPSC lines derived from fibroblasts by lentiviral reprogramming passed tests for mycoplasma infection, chromosomal aberrations, and pluripotency and were cultured maximum 60 passages. ${ }^{8,17}$ iPSCs were cultured and differentiated into MNs according to adapted protocols as described previously. ${ }^{8,18,19}$ In summary, iPSCs were aggregated into embryoid bodies and exposed to dual SMAD inhibition, retinoic acid, and smoothened agonist. The 
embryoid bodies were then dissociated and plated in single cell suspension on PDL-laminin coated coverslips and cocultured with mouse glia in neuronal medium containing neurotrophic factors brain-derived neurotrophic factor, glial cell-derived neurotrophic factor, and ciliary neurotrophic factor. In agreement with previous publications, the resulting neuronal cultures consisted of up to $50 \%$ of MNs, as identified by the expression of MN markers FoxP1, ChAT, and Isl1. ${ }^{8,18,19}$ Despite this heterogeneity of MN cultures, GM1 expression assessed with its high-affinity ligand cholera toxin subunit $B$ was uniform and present on all cells.

The Schwann cell line sNF96.2 (ATCC, CRL-2884) was derived from a malignant peripheral nerve sheath tumor and found positive for cytoplasmic Schwann cell markers S100 and $\mathrm{p} 75$. Cholera toxin B subunit confirmed GM1 expression. Cells were cultured in T75 or T175 flasks (Greiner) in DMEM medium (Life Technologies) supplemented with 100 $\mathrm{U} / \mathrm{mL}$ penicillin, $100 \mu \mathrm{g} / \mathrm{mL}$ streptomycin (both from Life Technologies), and 10\%, v/v, fetal calf serum (FCS; Bodinco) at $37^{\circ} \mathrm{C}$ at $5 \%, \mathrm{v} / \mathrm{v}, \mathrm{CO}_{2}$. Cells were passaged or collected for experiments twice weekly, when confluency was $>80 \%$. Passaging was performed by washing in $10 \mathrm{~mL}$ phosphatebuffered saline, pH 7.4 (PBS; Sigma-Aldrich), incubating in 3 or $5 \mathrm{~mL}$ Accutase cell detachment solution (eBioscience) at $37^{\circ} \mathrm{C}$, adding 7 or $10 \mathrm{~mL}$ culture medium and centrifuging (10 minutes at $125 \mathrm{~g}$ ), and pellets were resuspended in $10 \mathrm{~mL}$ culture medium. Cells were counted using a CASYton cell counter (OMNI Life Science).

\section{Microscopy}

MNs were seeded 80,000-150,000 cells per 13-mm coverslips (VWR) in 24-well plates (Greiner) and matured for 12-14 days, and SCs were seeded at a density of 10.000 cells/well on coverslips in 24-well plates and grown for 2 days at $37^{\circ} \mathrm{C}$, $5 \%, \mathrm{v} / \mathrm{v}, \mathrm{CO}_{2}$. Cells were fixed using 4\% PFA (Klinipath) for 10 minutes at room temperature $(\mathrm{RT})(\mathrm{MNs})$ or $4^{\circ} \mathrm{C}(\mathrm{SCs})$ and stored in PBS at $4^{\circ} \mathrm{C}$ until usage. Before removal from 24well plate, fixed cells were washed 3 times with $0.5 \mathrm{~mL}$ PBS. The remaining incubations were performed by placing coverslips top-down in $100 \mu \mathrm{L}$ droplets on parafilm and washing by dipping in PBS: $50 \mathrm{mM} \mathrm{NH}_{4} \mathrm{Cl}$ for 5 minutes at RT to quench autofluorescence, 1× wash, blocking with PBS-2\% BSA (Fraction V, Sigma) for 2 hours RT, wash, heatinactivated MMN patient serum 1:50 in PBS-2\% BSA for 1 hour at RT, $1 \times$ wash. Then, coverslips were incubated top-up with $15 \% \mathrm{v} / \mathrm{v}$ complement-active human pooled serum (with or without preincubation with complement blocking antibodies) for 30 minutes at RT and washed once in PBS. Subsequently, cells were incubated top-down with antibodies diluted in PBS-2\% BSA for 1 hour at RT in the dark and washed with PBS. Finally, cells were washed with PBS and distilled water (Milli-Q). After wicking of excess liquid on a tissue, coverslips were mounted on an object glass in $7 \mu \mathrm{L}$ ProLong Diamond Antifade Mountant with DAPI (Invitrogen) and dried overnight at RT. Cells were analyzed using a Zeiss Z1 microscope (Carl Zeiss Microscopy) with Colibri LEDs with the following settings: $\times 20$ magnification, $25 \%$ LED, $400 \mathrm{~ms}$ for Alexa Fluor 488 channel, $100 \mathrm{~ms}$ for APC channel, and $50 \mathrm{~ms}$ for DAPI channel (unless otherwise indicated in the respective experiment). Four pictures were taken per condition throughout the image field. All pictures were exported in single and merged channel to noncompressed TIFF-format using ZEN 2 software (Carl Zeiss Microscopy). Mean Gray Value was calculated of each single channel using ImageJ (Fiji $1.51 \mathrm{~g}$ ).

\section{Flow Cytometry}

For SCs, surface staining for complement receptors and other membrane proteins was measured by fluorescent-activated cell sorting (FACS), which allows higher throughput than microscopy (which was difficult to optimize for MNs). SCs were transferred to V-bottom plates (Greiner) at a density of 50,000 cells/well. Cells were stained with respective antibodies (see Antibodies and Reagents) diluted in FACS buffer (PBS-1\% BSA-0.01\% sodium azide) for 45 minutes on ice in the dark. Cells were washed once before, between, and after antibody incubations by adding $100 \mu \mathrm{L}$ FACS buffer and centrifuging for 5 minutes at $125 \mathrm{~g}$. Finally, cells were resuspended in $100 \mu \mathrm{L}$ FACS buffer and analyzed using a FACS Canto II and accompanying FACS DIVA software (BD Biosciences). When applicable, cells were washed in ice cold PBS and in $100 \mu \mathrm{L}$ Annexin V binding buffer (BD Biosciences) and stained with cell death markers PE Annexin V (BD Biosciences) and 7-AAD (BD Pharmingen) for 15 minutes at RT, before FACS analysis.

To assess complement activation, cells were opsonized with $20 \mu \mathrm{L}$ final volume of MMN heat-inactivated patient serum (1:20 dilution in veronal buffer (Lonza) supplemented with $\mathrm{CaCl}_{2}$ to a final concentration of $1.25 \mathrm{mM}$ (VB-Ca)) for 1 hour at RT. Next, cells were washed with $100 \mu \mathrm{L}$ VB-Ca. When applicable, SCs were subjected to PL-C (Invitrogen) treatment $\left(0.5 \mathrm{U} / \mathrm{mL}, 1\right.$ hour $\left.37^{\circ} \mathrm{C}\right)$ before opsonization. Next, the supernatant was discarded, and cells were incubated for 1 hour at $37^{\circ} \mathrm{C}$ with $100 \mu \mathrm{L}$ fresh serum diluted $1: 20$ in VBCa. This serum was preincubated with EDTA, serum components, or respective antibodies for 15 minutes at RT. After incubation, cells were centrifuged and stained for fixed complement factors according to the above-mentioned staining protocol.

\section{Statistics}

GraphPad Prism 8 (GraphPad Software) was used for all statistical analyses and visualization of the data. Correlation between parameters was evaluated using Spearman rank correlation coefficient analysis. A 2-sided $p<0.05$ was considered to be statistically significant.

\section{Data Availability}

Anonymized data and documentation of this study will be shared on reasonable request from any qualified researcher. Standard data sharing agreements apply. 


\section{Results}

\section{IgM-Anti-GM1 Antibodies in Sera From Patients With MMN Bind to MNs}

Twenty MMN patient sera were used for analyses. On incubation with these sera, binding of IgM to iPSC MNs was observed (Figure 1A), although this binding was different among patients (Figure 1A, quantified in Figure 1B). Staining intensities significantly correlated with anti-GM1 ELISA titers (Figure 1C, $r_{s}: 0.87, p<0.0001$ ).

\section{Expression of Complement-Related Membrane Proteins by iPSC MNs}

To prevent complement-mediated damage, cells are equipped with membrane-bound complement regulatory proteins (mCRPs) CD46, CD55, and CD59. CD46 functions as cofactor for factor I-mediated cleavage of $\mathrm{C} 3 \mathrm{~b}$ and C4b, CD55 inhibits C 3 activation by accelerating the decay of C3 convertase, and CD59 inhibits MAC formation. ${ }^{13,20}$ All mCRPs are expressed by MNs (Figure 2A), with the highest expression found for CD59, whereas that of CD55 and $\mathrm{CD} 46$ was lower. The receptor for the anaphylatoxin C3a, C3aR, was also expressed by MNs, as well as lower levels of $\mathrm{C} 5 \mathrm{aR}$ and $\mathrm{C} 3 \mathrm{~b} / \mathrm{C} 4 \mathrm{~b}$ receptor CD35 (CR1). No expression was found for $\mathrm{iC} 3 \mathrm{~b}$ receptors $\mathrm{CD} 11 \mathrm{~b}$ (CR3), and CD11c (CR4) (Figure 2, A and B). High mCRP levels and lower expression of $\mathrm{C} 3 \mathrm{aR}$ were confirmed via $\mathrm{qPCR}$ (eFigure 1, links.lww.com/NXI/A652).

\section{IgM From Patients With MMN Activates Complement on Binding to MNs}

Using microscopy, fixed MNs were found to activate complement on sequential incubation with heat-inactivated MMN serum and fresh serum as complement source, as evidenced by binding of $\mathrm{C} 4$ and $\mathrm{C} 3$ to the cells. Preincubation of the fresh serum with $10 \mathrm{mM}$ EDTA completely abolished activation. Preincubation with the anti-C2 antibody ARGX-117 $(480 \mu \mathrm{g} / \mathrm{mL})$ prevented C3, but not $\mathrm{C} 4$, fixation, demonstrating a main role of the classical or lectin pathway in the activation of complement by $\operatorname{IgM}$ bound to MNs. An inhibitory anti-C5 mAb $(480 \mu \mathrm{g} / \mathrm{mL})$ had no effect on $\mathrm{C} 4$ or $\mathrm{C} 3$ fixation (Figure 3A). Opsonization with different $\mathrm{MMN}$ patient sera resulted in variable C3 fixation. C3 fixation to MNs correlated significantly with IgM staining of the cells $\left(r_{s}=0.60\right.$, Spearman rank correlation coefficient, $p=0.0055$, Figure $3 \mathrm{~B}$ ) and with IgM antiGM1 antibody titers determined with ELISA $\left(r_{s}=0.65, p=\right.$ 0.0019, Figure 3C).

Figure $1 \mathrm{GM} 1$ Expression and Binding of IgM to MNs

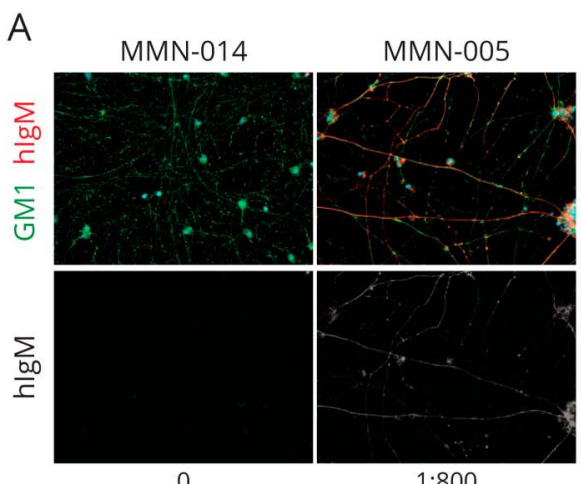

0

B

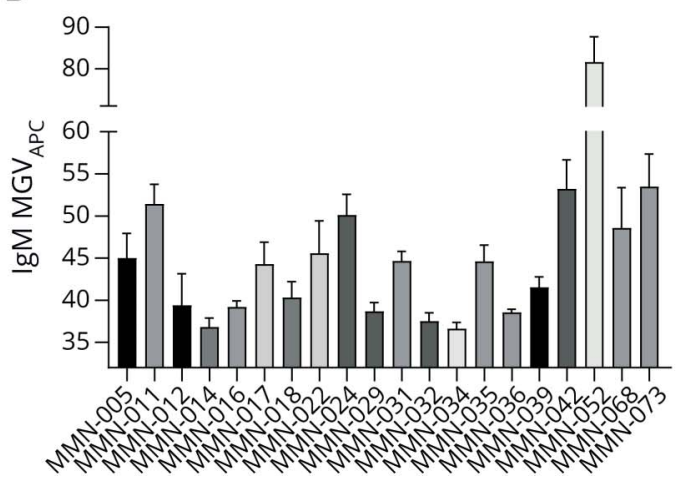

MMN-042
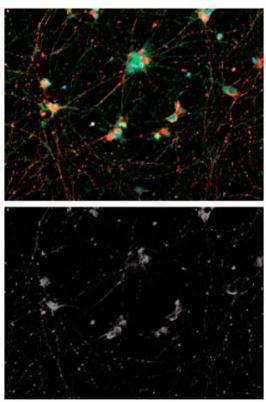

$1: 1,600$
MMN-024
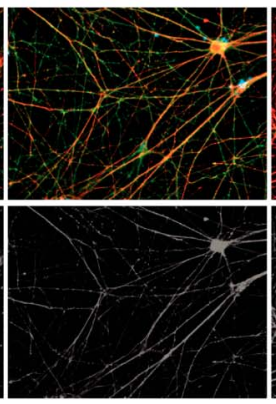

$1: 6,400$

C
MMN-052

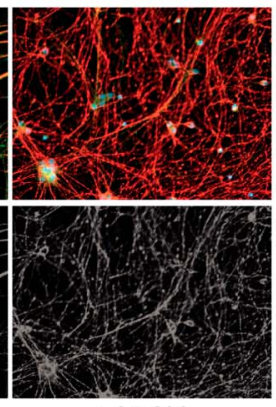

$1: 25,600$

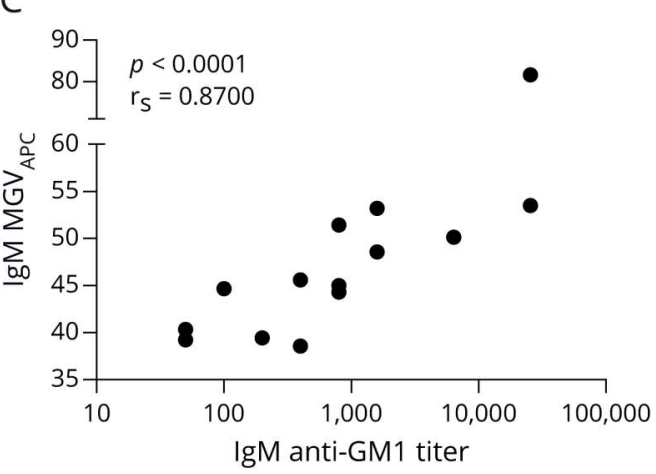

(A) Microscopic images depicting IgM staining of MNs on incubation with sera from 5 patients with MMN with different IgM anti-GM1 antibody titers. GM1 staining is shown in green, IgM staining is depicted in red, and DAPI in blue. Images were obtained using a Zeiss Z1 microscope (Carl Zeiss Microscopy) with Colibri LEDs with the following settings: $\times 20$ magnification, 25\% LED, 400 ms for Alexa FluorTM 488 channel, 100 ms for APC channel, and 50 ms for DAPI channel. (B) Quantification of the IgM binding intensity of induced pluripotent stem cell MNs on opsonization with different MMN patient sera. Data represent mean \pm SD of at least 4 representative individual pictures. (C) Spearman rank correlation of IgM binding signal and IgM anti-GM1 antibody titer as determined with ELISA of 15 patients with MMN. ${ }^{3}$ DAPI = 4'6-diamidino-2-phenylindole; $\mathrm{MMN}=$ multifocal motor neuropathy; $\mathrm{MN}=$ motor neuron. 

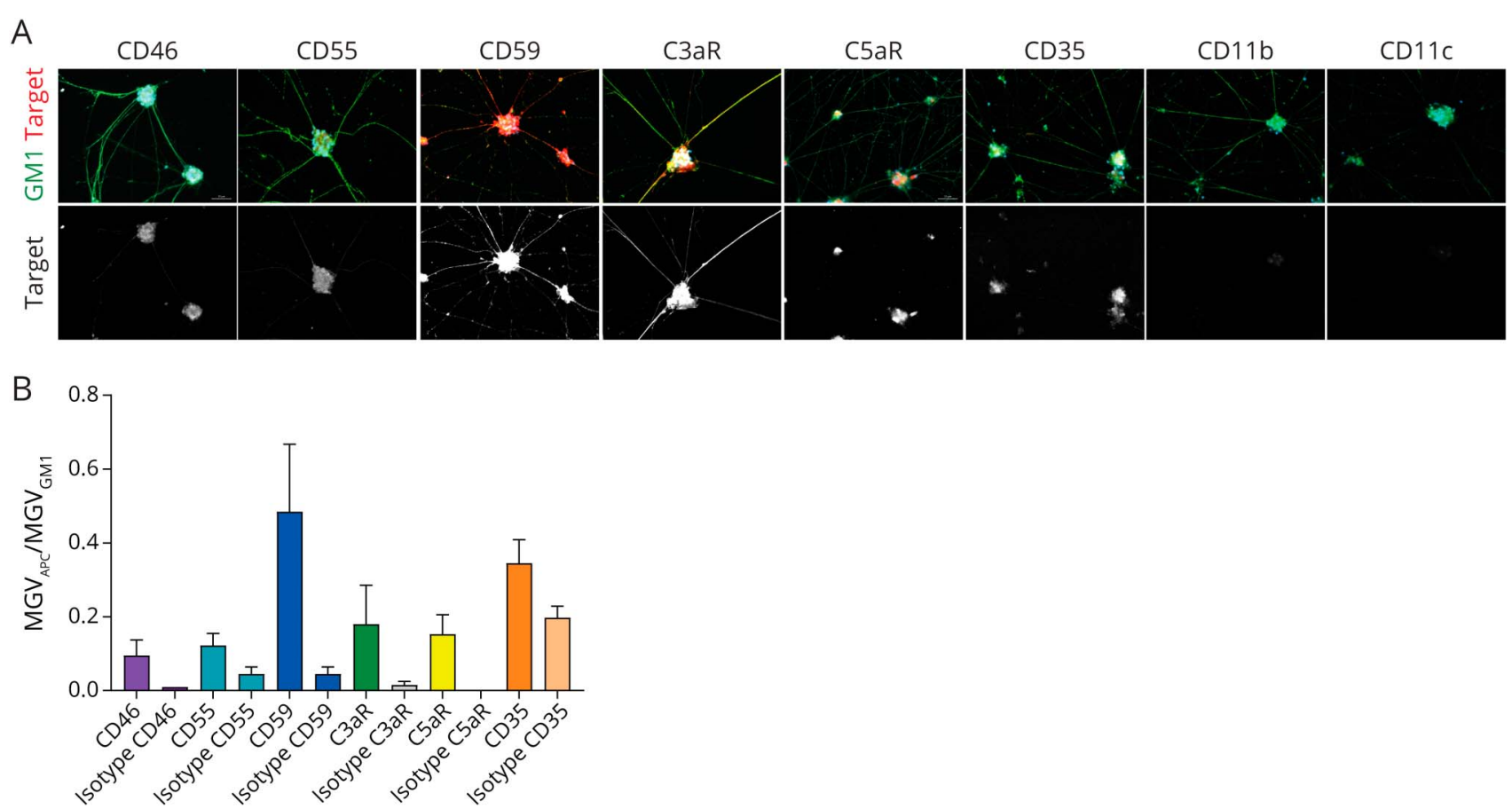

(A) Expression of mCRPs CD46, CD55, CD59, and C3aR, C5aR, CD35, CD11b, and CD11c. GM1 staining is shown in green, the indicated membrane protein in red, and DAPI in blue. Images were obtained using a Zeiss Z1 microscope (Carl Zeiss Microscopy) with Colibri LEDs with the following settings: $\times 20$ magnification, 25\% LED, 400 ms for Alexa FluorTM 488 channel, 100 ms for APC channel, and 50 ms for DAPI channel. Quantification of microscopic data, including isotype controls, is shown in B (mean \pm SD of at least 4 representative individual pictures). DAPI = 4'6-diamidino-2-phenylindole; $\mathrm{MN}=$ motor neuron.

\section{Expression of mCRPs Protects Against IgM Anti-GM1-Induced Complement-Mediated Cell Lysis}

High levels of CD59 protect cells against complementdependent cytotoxicity. For technical reasons, we could not study the effect of CD59 on complement cytotoxicity of MNs. Therefore, we used a GM1/CD59-positive cell line to study the protective effect of CD59 after IgM anti-GM1 initiated complement activation. The Schwann cell line sNF96.2 expresses GM1 and complement regulatory proteins CD59 and CD55. Incubation of sNF96.2 cells with MMN patient serum indeed showed IgM binding to these cells (Figure 4, A and B). Treatment of SCs with phospholipase $C$ reduced expression of GPI-linked CD55 and CD59 but not that of transmembrane CD46 or GM1 (Figure 4A). Using Annexin V/7-AAD staining to assess pore formation in the cell membrane, we confirmed viability of SCs after incubation with IgM anti-GM1 containing MMN patient serum and complement. In contrast, SCs with strongly reduced CD55 and CD59 levels became permeable on opsonization and complement activation as evidenced by an increase in numbers of Annexin V/7-AAD double-positive cells. This cytotoxic effect of complement was dependent on opsonization of the cells with MMN serum and was not observed without opsonization (VB only, Figure 4C). Reduced protection against complement activation was also reflected by increased C3 and MAC deposition onto SCs that survived complement cytotoxicity (Figure 4, D and E). Thus, CD59expressing cells are protected against complement activation induced by IgM anti-GM1, presumably at the level of MAC formation and insertion in the cell membrane.

\section{ARGX-117 Inhibits IgM-Mediated Classical Pathway Complement Activation on MNs}

ARGX-117 is a novel inhibitory mAb against $\mathrm{C} 2$ that blocks the classical and lectin pathway upstream of $\mathrm{C} 3$ convertase formation. To estimate the $\mathrm{C} 2$ dependency of complement activation by MNs sensitized with serum from patients with MMN, C3 fixation was investigated using $\mathrm{C} 2$-depleted serum supplemented with various amounts of $\mathrm{C} 2$, as complement source. C3 fixation on MNs was abrogated when C2-depleted serum was used (Figure 5,A and B). Reconstitution of depleted serum with C2 up to physiologic levels $(30 \mu \mathrm{g} / \mathrm{mL})$ dose dependently restored C3 fixation (Figure 5, A and B). Next, complement-active sera were incubated with ARGX-117 $(200,50,12,3 \mu \mathrm{g} / \mathrm{mL})$ before incubation with sensitized MNs (Figure 5, C and D). ARGX-117 strongly inhibited C3 fixation on MNs by $>90 \%$ at approximately equimolar concentrations $(50 \mu \mathrm{g} / \mathrm{mL})$ to $\mathrm{C} 2$.

\section{Discussion}

In this study, we investigated complement activation by antiGM1 IgM antibodies from MMN patient sera in a disease model for MMN and characterized expression of complement receptors and membrane-bound complement regulators on iPSC-derived MNs. We found that IgM anti-GM1 binding to 
A
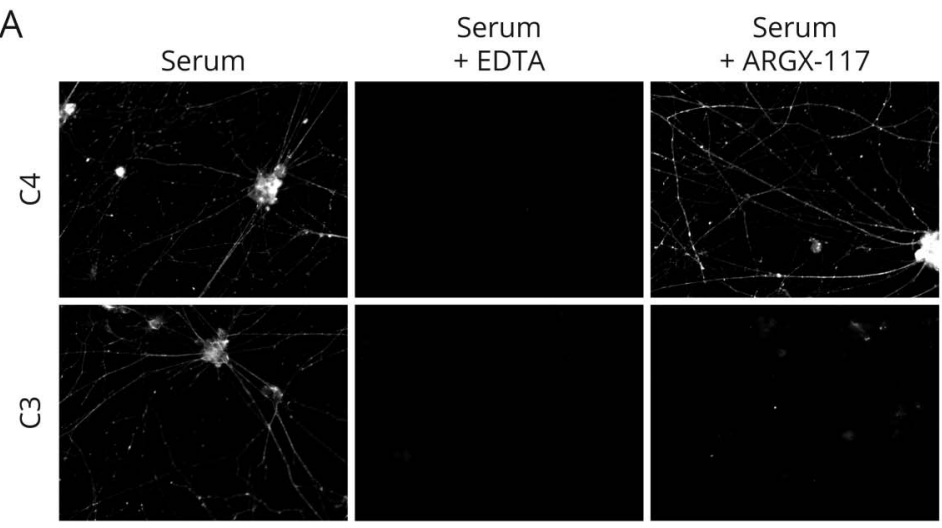

c

B

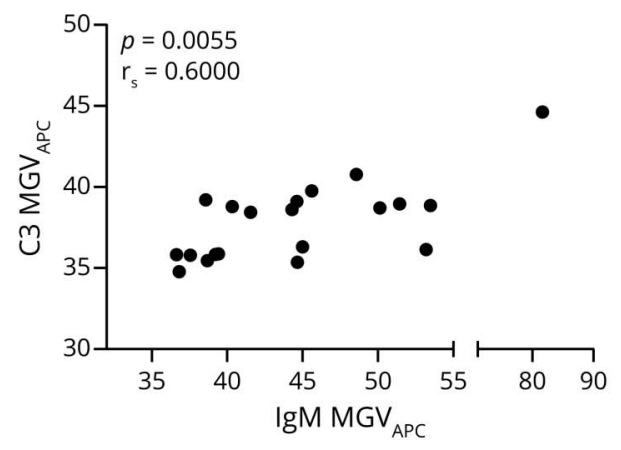

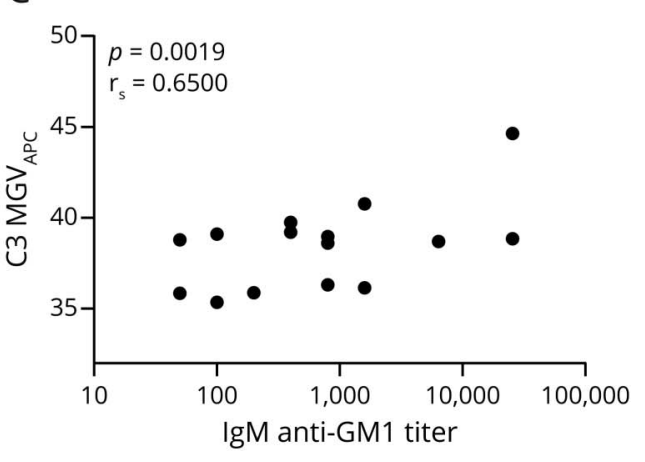

(A) MNs were incubated with heatinactivated MMN serum, followed by incubation with fresh serum in the presence or absence of inhibitory anticomplement antibodies. Preincubation of fresh serum with EDTA abrogates complement fixation. ARGX-117 abrogates fixation of $\mathrm{C} 3$, but not $\mathrm{C} 4$. Anti-C5 does not prevent either C4 or C3 fixation. Images were obtained using a Zeiss Z1 microscope (Carl Zeiss Microscopy) with Colibri LEDs with the following settings: $\times 20$ magnification, 25\% LED, 400 ms for Alexa FluorTM 488 channel, $100 \mathrm{~ms}$ for APC channel, and $50 \mathrm{~ms}$ for 4'6-diamidino-2-phenylindole channel. (B) IgM anti-GM1 binding correlates with C3 staining after incubation with complement-active human serum (Spearman correlation coefficient; $r_{s}=0.60, p=0.0055$ ). (C) An increase in IgM anti-GM1 antibody titers translates into an increase in C3 staining after complement activation (Spearman correlation coefficient.; $r_{\mathrm{s}}$ $=0.65, p=0.0019)$. EDTA $=$ ethylenediamine tetraacetic acid; $\mathrm{MMN}=$ multifocal motor neuropathy; $\mathrm{MN}=$ motor neuron.
MNs triggers complement activation, which is dependent on C2, and does not induce lysis because of CD59 expression. This activation is effectively inhibited by a novel antibody targeting C2, ARGX-117. Thus, C2 represents a promising new target for the treatment of $\mathrm{MMN}$.

The disease model used in this study lacks the interplay between SCs and MNs and does not account for myelination or the formation of the nodes of Ranvier, which are implicated in the pathogenesis of $\mathrm{MMN}^{1,2,5}$ Despite these limitations, we believe that the in vitro model in its current form is suitable for studying some mechanistic aspects of the potential pathologic effects of IgM anti-GM1 antibodies and evaluate novel treatment strategies, ${ }^{8}$ especially because suitable animal models for MMN are lacking.

The binding of IgM to iPSC-derived MNs in this disease model correlated with IgM anti-GM1 antibody titers determined with ELISA, ${ }^{3}$ implying that most IgM bound to iPSC-derived MNs is directed against GM1. Importantly, both IgM anti-GM1 antibody titers and IgM binding to MNs significantly correlated with complement activation, as reflected by $\mathrm{C} 3$ fixation. This confirms earlier results with ELISAs that IgM anti-GM1 antibody titers correlate with complement fixation ${ }^{7}$ and our previous report that IgM antiGM1 also activates complement in an iPSC-model for MMN. ${ }^{8}$ Because anti-GM1 antibodies in MMN are almost exclusively of the IgM isotype, ${ }^{21}$ the main effector system recruited by these autoantibodies is complement activation, in particular via the classical pathway, although some human IgM also can activate the lectin pathway of complement. ${ }^{22}$

iPSC-derived MNs express the mCRPs CD46 and CD55 and in particular CD59. These expression patterns not only are consistent with postmortem and biopsy studies of the sciatic nerve and of primary cells cultured from sural nerves ${ }^{23-25}$ but also predict protection against the cytotoxic effects of MAC. For technical reasons, such protective effect could not be demonstrated with iPSC-derived MNs, but was demonstrated for SCs that also express GM1 and mCRPs. Removal of CD55 and CD59 made these cells highly sensitive to lysis by antiGM1 induced complement activation (Figure 4).

Because iPSC-derived MNs express the anaphylatoxin receptors $\mathrm{C} 3 \mathrm{aR}$ and $\mathrm{C} 5 \mathrm{aR}$, fluid-phase complement activation products, such as $\mathrm{C} 3 \mathrm{a}$ or $\mathrm{C} 5 \mathrm{a}$, may play a dominant role in the pathophysiology of $\mathrm{MMN} .^{26}$ Overall, the data on expression of mCRPs and CRs suggest that MNs and SCs possess sophisticated complement sensing and modulating capacities, ${ }^{27,28}$ the biological relevance of which needs to be further elucidated.

IV immunoglobulins are the only approved treatment for MMN. ${ }^{9,10}$ IVIg may contain IgG antineuronal antibodies, and it has been proposed that these could elevate titers of presumed pathogenic antibodies. ${ }^{29}$ The samples used in the 
A

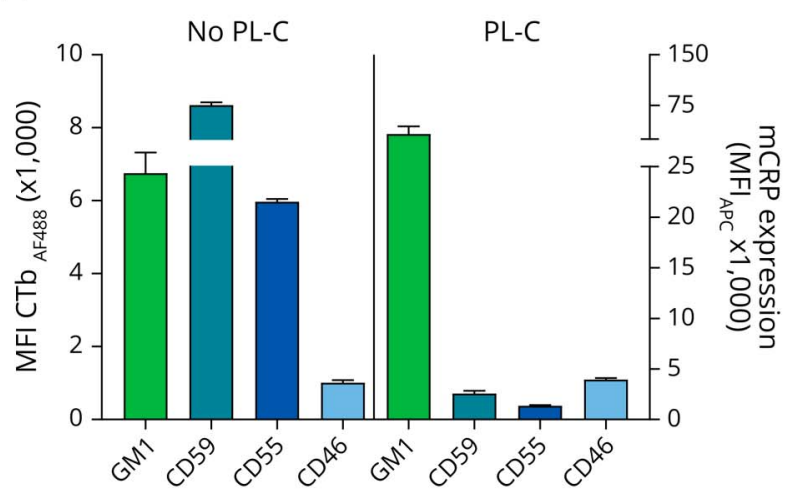

C

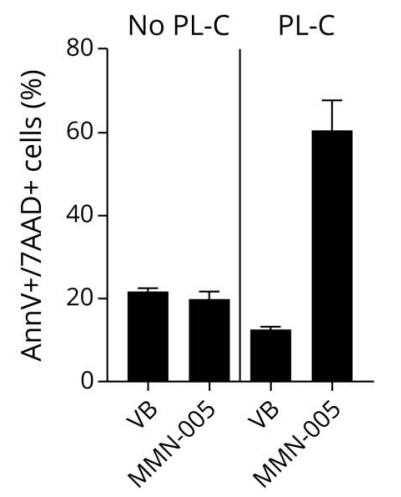

B

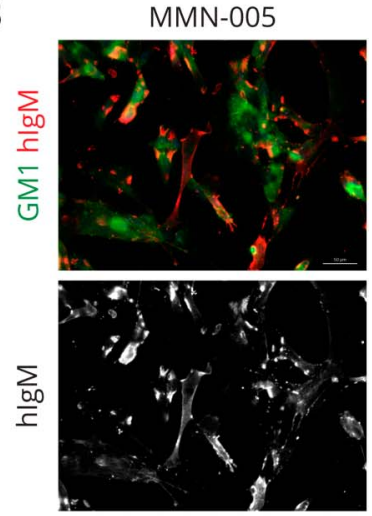

E

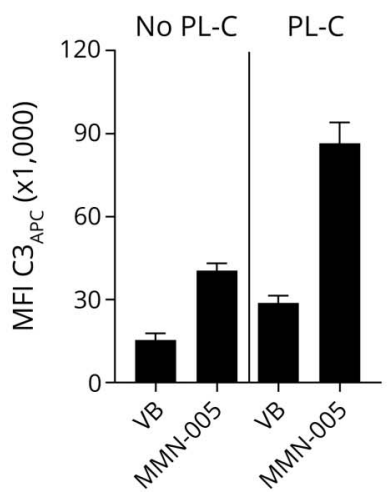

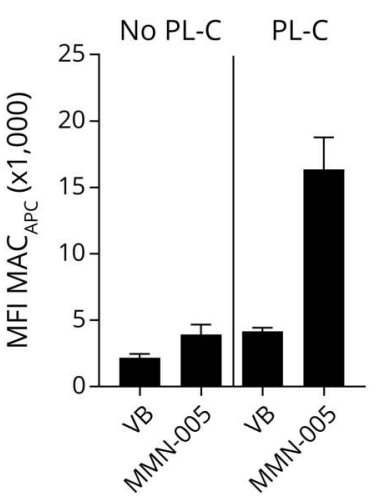

(A) sNF96.2 cells express GM1 and CD59. Pretreatment of SCs with phospholipase $C$ reduces expression of GPIlinked CD55 and CD59, but not of transmembrane CD46 or GM1. (B) MMN patient-derived IgM antibodies bind to GM1-expressing sNF96.2 cells. GM1 staining is shown in green and IgM staining in red. Images were obtained using a Zeiss Z1 microscope (Carl Zeiss Microscopy) with Colibri LEDs with the following settings: $\times 20$ magnification, 25\% LED, 400 ms for Alexa FluorTM 488 channel, $100 \mathrm{~ms}$ for APC channel, and $50 \mathrm{~ms}$ for 4'6- diamidino-2-phenylindole channel. (C) On activation with heat-inactivated MMN serum and fresh serum, SCs with intact CD55 and CD59 expression display no lysis, as measured with Annexin $\mathrm{V}$ and 7-AAD staining, C3 fixation (D), or MAC insertion (E). Data represent mean \pm SEM of 3 independent experiments. $\mathrm{MAC}=$ membrane attack complex; $\mathrm{MMN}=$ multifocal motor neuropathy; $\mathrm{MN}=$ motor neuron. present study were previously screened using a GM1 ELISA. IgG anti-GM1 was only detected in 1 of 110 patients with MMN, and this patient was not included in this study. ${ }^{30}$ The strong correlation between IgM anti-GM1 titers in the ELISA, IgM binding, and subsequent $\mathrm{C} 3$ fixation to $\mathrm{MNs}$ suggested that IgM anti-GM1 antibodies are the major driver of complement activation in the MMN disease model. Because IVIg contains only trace amounts of $\operatorname{IgM},{ }^{31}$ it is not a likely source of pathogenic IgM anti-GM1 antibodies.

Among the proposed immune modulatory effects of IVIg is inhibition of complement activation at multiple levels, including deposition of C3 on activators. ${ }^{32-34}$ Indeed, IVIg infusion reduces classical complement activity in patients with $\mathrm{MMN}$, whereas titers and complement-activating capacity of IgM anti-GM1 remained unchanged. ${ }^{15}$ To avoid a potential interference of IVIg in the assays described here, we used heat-inactivated MMN serum to opsonize the cells, subsequently washed these to remove patient serum including IVIg when present, and then added fresh normal human serum as complement source. Therefore, IVIg treatment of the patients with MMN has not influenced the results of our study.

The results of our study may explain the negative outcome of an open-label trial using eculizumab, an anti-C5 $\mathrm{mAb}$, in addition to IVIg maintenance therapy. ${ }^{35}$ Considering their high CD59 expression, iPSC-derived MNs seem to have a high innate ability to inhibit the terminal part of the complement cascade. Targeting C5 to preserve the function of MNs on complement activation by anti-GM1 IgM antibodies may therefore have limited effect. Moreover, C5 is downstream of $\mathrm{C} 3$, whereas the presence of $\mathrm{C} 3 \mathrm{aR}$ on $\mathrm{MNs}$ suggests that complement activation upstream of C5 may have functional consequences for MNs. Therefore, targeting $\mathrm{C} 2$, which is at the junction of the classical and lectin pathway, seems an interesting approach in MMN, the more because IgM can activate both pathways. Moreover, the clinical phenotype of a $\mathrm{C} 2$ deficiency is less severe than that of $\mathrm{C} 3$ or $\mathrm{C} 4$ deficiency. ${ }^{36,37}$ ARGX-117, a novel potent antibody targeting $\mathrm{C} 2{ }^{16}$, indeed abrogates C3 fixation induced by IgM anti-GM1 on MNs in a concentration-dependent manner (Figure 5).

In conclusion, we have characterized complement activation by GM1 autoantibodies derived from patients with MMN, using iPSC-derived MNs as an ex vivo disease model for MMN. Patientderived IgM antibodies bind to iPSC MNs and activate complement. These results emphasize the role of IgM anti-GM1 and complement in MMN pathogenesis. Moreover, complement activation by IgM anti-GM1 on MNs can be effectively inhibited by targeting C2 using ARGX-117. Considering that IVIg treatment, though effective in $\mathrm{MMN}$, can often not prevent a progressive disease course, we propose based on the data described here, to evaluate ARGX-117 as a treatment of MMN. 

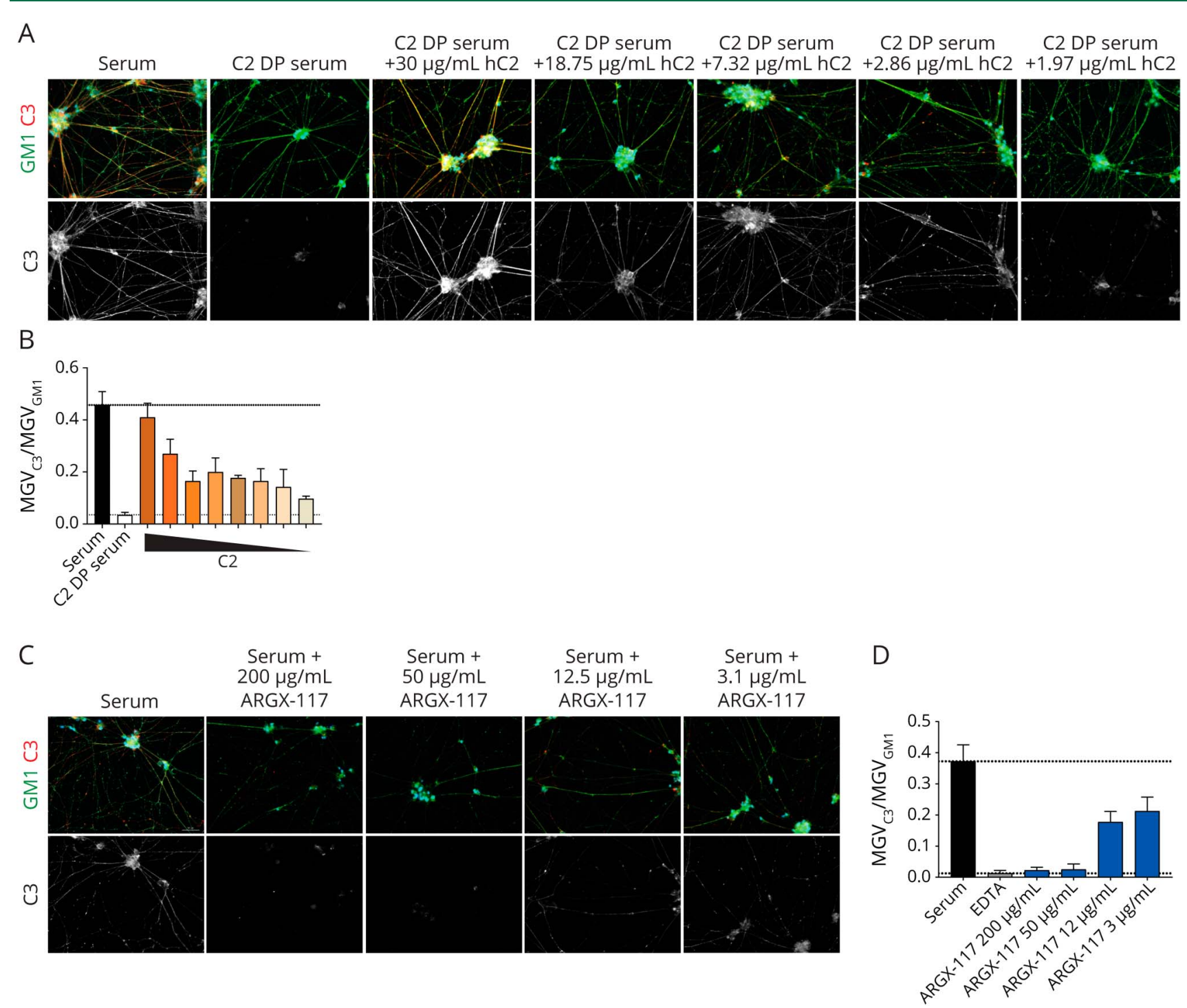

(A) MNs were incubated with heat-inactivated MMN serum, followed by incubation with C2-depleted serum (C2-DP) containing increasing amounts of C2 and stained for GM1 (green), C3 (red), and DAPI (blue) with fluorescent microscopy. Quantification of the data in A is shown in B (mean and SD of 4 individual representative pictures). The concentrations of C2 in C2-depleted serum supplemented are indicated and were 30, 18.75, 11.72, 7.32, 4.58, 2.86, 1.97, and $1.11 \mu \mathrm{g} / \mathrm{mL}$, respectively. (C) ARGX-117 added to normal serum dose dependently inhibits C3 fixation on MNs sensitized with IgM from MMN patients as measured with fluorescent microscopy. GM1 staining is shown in green, C3 in red, and DAPI in blue. Quantification of the data in C is shown in D as mean and SD of 4 individual representative pictures. Images were obtained using a Zeiss Z1 microscope (Carl Zeiss Microscopy) with Colibri LEDs with the following settings: $\times 20$ magnification, 25\% LED, 400 ms for Alexa FluorTM 488 channel, 100 ms for APC channel, and 50 ms for DAPI channel. DAPI = 4'6-diamidino-2phenylindole; $\mathrm{MMN}=$ multifocal motor neuropathy; $\mathrm{MN}=$ motor neuron.

\section{Study Funding}

No targeted funding reported.

\section{Disclosure}

I. van de walle, H. de Haard, C. Blanchetot, and L. van de Ven: employees and equity ownership in argenx BVBA. C. Erik Hack: employee of Prothix BV and providing consultancy services for argenx BVBA. P. Boross: employee of Prothix BV. K. Silence: providing consultancy services for argenx BVBA. W. Ludo van der Pol serves on the scientific advisory board for SAB SMA Europe; provides ad hoc consultancy for argenx, Biogen, and AveXis; and receives research support from the Prinses Beatrix Spierfonds, Vriendenloterij and Stichting Spieren voor Spieren. L. H. van den Berg serves on scientific advisory boards for Orion, Biogen, and Cytokinetics; received an educational grant from Takeda; serves on the editorial boards of Amyotrophic Lateral Sclerosis and Frontotemporal Degeneration and the Journal of Neurology, Neurosurgery, and Psychiatry; and receives research support from the Prinses Beatrix Spierfonds, Netherlands ALS Foundation, and the Netherlands Organisation for Health Research and Development (Vici Scheme, JPND [SOPHIA, STRENGTH, ALSCare]). Go to Neurology.org/NN for full disclosures. 
Publication History

Received by Neurology: Neuroimmunology \& Neuroinflammation December 18, 2020. Accepted in final form September 10, 2021.

Appendix Authors

\begin{tabular}{|c|c|c|}
\hline Name & Location & Contribution \\
\hline $\begin{array}{l}\text { Kevin Budding, } \\
\text { PhD }\end{array}$ & $\begin{array}{l}\text { Center for Translational } \\
\text { Immunology, University } \\
\text { Medical Center Utrecht, } \\
\text { Utrecht University, Utrecht, } \\
\text { The Netherlands }\end{array}$ & $\begin{array}{l}\text { Drafting/revision of the } \\
\text { manuscript for content, } \\
\text { including medical writing } \\
\text { for content; major role in } \\
\text { the acquisition of data; } \\
\text { study concept or design; } \\
\text { and analysis or } \\
\text { interpretation of data }\end{array}$ \\
\hline $\begin{array}{l}\text { Lill Eva } \\
\text { Johansen, MSc }\end{array}$ & $\begin{array}{l}\text { Department of Neurology } \\
\text { and Neurosurgery, } \\
\text { University Medical Center } \\
\text { Utrecht Brain Center, } \\
\text { Utrecht University, Utrecht, } \\
\text { The Netherlands; } \\
\text { Department of } \\
\text { Translational Neuroscience, } \\
\text { University Medical Center } \\
\text { Utrecht Brain Center, } \\
\text { Utrecht University, Utrecht, } \\
\text { The Netherlands }\end{array}$ & $\begin{array}{l}\text { Drafting/revision of the } \\
\text { manuscript for content, } \\
\text { including medical writing } \\
\text { for content; major role in } \\
\text { the acquisition of data; } \\
\text { study concept or design; } \\
\text { and analysis or } \\
\text { interpretation of data }\end{array}$ \\
\hline $\begin{array}{l}\text { Inge Van de } \\
\text { Walle, PhD }\end{array}$ & $\begin{array}{l}\text { argenx BVBA, } \\
\text { Industriepark-Zwijnaarde } \\
7, \text { Zwijnaarde, Belgium }\end{array}$ & $\begin{array}{l}\text { Drafting/revision of the } \\
\text { manuscript for content, } \\
\text { including medical writing } \\
\text { for content; study concept } \\
\text { or design; and analysis or } \\
\text { interpretation of data }\end{array}$ \\
\hline $\begin{array}{l}\text { Kim } \\
\text { Dijkxhoorn, BSc }\end{array}$ & $\begin{array}{l}\text { Center for Translational } \\
\text { Immunology, University } \\
\text { Medical Center Utrecht, } \\
\text { Utrecht University, Utrecht, } \\
\text { The Netherlands }\end{array}$ & $\begin{array}{l}\text { Drafting/revision of the } \\
\text { manuscript for content, } \\
\text { including medical writing } \\
\text { for content; major role in } \\
\text { the acquisition of data; and } \\
\text { analysis or interpretation } \\
\text { of data }\end{array}$ \\
\hline $\begin{array}{l}\text { Elisabeth de } \\
\text { Zeeuw, MSc }\end{array}$ & $\begin{array}{l}\text { Center for Translational } \\
\text { Immunology, University } \\
\text { Medical Center Utrecht, } \\
\text { Utrecht University, Utrecht, } \\
\text { The Netherlands }\end{array}$ & $\begin{array}{l}\text { Major role in the } \\
\text { acquisition of data and } \\
\text { analysis or interpretation } \\
\text { of data }\end{array}$ \\
\hline $\begin{array}{l}\text { Lauri M. } \\
\text { Bloemenkamp, } \\
\text { BSc }\end{array}$ & $\begin{array}{l}\text { Center for Translational } \\
\text { Immunology, University } \\
\text { Medical Center Utrecht, } \\
\text { Utrecht University, Utrecht, } \\
\text { The Netherlands; } \\
\text { Department of Neurology } \\
\text { and Neurosurgery, } \\
\text { University Medical Center } \\
\text { Utrecht Brain Center, } \\
\text { Utrecht University, Utrecht, } \\
\text { The Netherlands; } \\
\text { Department of } \\
\text { Translational Neuroscience, } \\
\text { University Medical Center } \\
\text { Utrecht Brain Center, } \\
\text { Utrecht University, Utrecht, } \\
\text { The Netherlands }\end{array}$ & $\begin{array}{l}\text { Major role in the } \\
\text { acquisition of data and } \\
\text { analysis or interpretation } \\
\text { of data }\end{array}$ \\
\hline $\begin{array}{l}\text { Jeroen W. Bos, } \\
\text { MD }\end{array}$ & $\begin{array}{l}\text { Department of Neurology } \\
\text { and Neurosurgery, } \\
\text { University Medical Center } \\
\text { Utrecht Brain Center, } \\
\text { Utrecht University, Utrecht, } \\
\text { The Netherlands }\end{array}$ & $\begin{array}{l}\text { Analysis or interpretation } \\
\text { of data }\end{array}$ \\
\hline
\end{tabular}

Appendix (continued)

\begin{tabular}{lll}
\hline Name & Location & Contribution \\
\hline $\begin{array}{ll}\text { Marc D. Jansen, } \\
\text { BSc }\end{array}$ & $\begin{array}{l}\text { Department of Neurology } \\
\text { and Neurosurgery, } \\
\text { University Medical Center } \\
\text { Utrecht Brain Center, } \\
\text { Utrecht University, Utrecht, } \\
\text { The Netherlands }\end{array}$ & $\begin{array}{l}\text { Major role in the } \\
\text { acquisition of data and } \\
\text { analysis or interpretation } \\
\text { of data }\end{array}$ \\
& \\
\hline
\end{tabular}

\begin{tabular}{lll}
\hline $\begin{array}{l}\text { Chantall A.D. } \\
\text { Curial, BSc }\end{array}$ & $\begin{array}{l}\text { Department of Neurology } \\
\text { and Neurosurgery, } \\
\text { University Medical Center } \\
\text { Utrecht Brain Center, } \\
\text { Utrecht University, Utrecht, } \\
\text { The Netherlands }\end{array}$ & $\begin{array}{l}\text { Major role in the } \\
\text { acquisition of data and } \\
\text { analysis or interpretation } \\
\text { of data }\end{array}$ \\
\hline $\begin{array}{l}\text { Karen Silence, } \\
\text { PhD }\end{array}$ & $\begin{array}{l}\text { Argenx BVBA, } \\
\text { Industriepark-Zwijnaarde }\end{array}$ & $\begin{array}{l}\text { Study concept or design } \\
\text { and analysis or } \\
\text { interpretation of data }\end{array}$ \\
\hline $\begin{array}{l}\text { 7, Zwijnaarde, Belgium } \\
\text { Phans de Haard, }\end{array}$ & $\begin{array}{l}\text { Argenx BVBA, } \\
\text { Industriepark-Zwijnaarde }\end{array}$ & $\begin{array}{l}\text { Study concept or design } \\
\text { and analysis or } \\
\text { interpretation of data }\end{array}$ \\
\hline $\begin{array}{lll}\text { 7, Zwijnaarde, Belgium } \\
\text { Christophe } \\
\text { Blanchetot, } \\
\text { PhD }\end{array}$ & $\begin{array}{l}\text { Argenx BVBA, } \\
\text { Industriepark-Zwijnaarde }\end{array}$ & $\begin{array}{l}\text { Analysis or interpretation } \\
\text { of data }\end{array}$ \\
\hline
\end{tabular}

Liesbeth Van de Argenx BVBA,

Ven, MSc

Industriepark-Zwijnaarde of data

7, Zwijnaarde, Belgium

Jeanette H.W. Center for Translational Analysis or interpretation

Leusen, PhD Immunology, University of data

Medical Center Utrecht,

Utrecht University, Utrecht,

The Netherlands

\begin{tabular}{|c|c|c|}
\hline $\begin{array}{l}\text { R. Jeroen } \\
\text { Pasterkamp, } \\
\text { PhD }\end{array}$ & $\begin{array}{l}\text { Department of } \\
\text { Translational } \\
\text { Neuroscience, University } \\
\text { Medical Center Utrecht } \\
\text { Brain Center, Utrecht } \\
\text { University, Utrecht, The } \\
\text { Netherlands }\end{array}$ & Study concept or design \\
\hline
\end{tabular}

Leonard H. van Department of Neurology Study concept or design

den Berg, MD, and Neurosurgery,

PhD University Medical Center

Utrecht Brain Center,

Utrecht University, Utrecht,

The Netherlands

\begin{tabular}{|c|c|c|}
\hline $\begin{array}{l}\text { C. Erik Hack, } \\
\text { MD, PhD }\end{array}$ & $\begin{array}{l}\text { Center for Translational } \\
\text { Immunology, University } \\
\text { Medical Center Utrecht, } \\
\text { Utrecht University, Utrecht, } \\
\text { the Netherlands; Prothix, } \\
\text { Leiden, The Netherlands }\end{array}$ & $\begin{array}{l}\text { Drafting/revision of the } \\
\text { manuscript for content, } \\
\text { including medical writing } \\
\text { for content; study } \\
\text { concept or design; and } \\
\text { analysis or interpretation } \\
\text { of data }\end{array}$ \\
\hline
\end{tabular}

Peter Boross, Center for Translational Drafting/revision of the

PhD Immunology, University manuscript for content,

Medical Center Utrecht, including medical writing

Utrecht University, Utrecht, for content; study

the Netherlands; Prothix, concept or design; and

Leiden, The Netherlands analysis or interpretation

of data

W. Ludo van der Department of Neurology Drafting/revision of the

Pol, MD, PhD and Neurosurgery, manuscript for content,

University Medical Center including medical writing

Utrecht Brain Center, for content; study

Utrecht University, Utrecht, concept or design; and

The Netherlands analysis or interpretation of data 


\section{References}

1. Beadon K, Guimarães-Costa R, Léger JM. Multifocal motor neuropathy. Curr Opin Neurol. 2018;31(5):559-564.

2. Nobile-Orazio E. Multifocal motor neuropathy. J Neuroimmunol.2001;115(1-2):4-18.

3. Cats EA, van der Pol WL, Piepers S, et al. Correlates of outcome and response to IVIg in 88 patients with multifocal motor neuropathy. Neurology. 2010;75(9):818-825.

4. Morikawa M, Kuwahara M, Ueno R, Samukawa M, Hamada Y, Kusunoki S. Serological study using glycoarray for detecting antibodies to glycolipids and glycolipid complexes in immune-mediated neuropathies. J Neuroimmunol. 2016;301:35-40.

5. Martinez-Thompson JM, Snyder MR, Ettore M, et al. Composite ganglioside autoantibodies and immune treatment response in MMN and MADSAM. Muscle Nerve. 2018;57(6):1000-1005.

6. Yeh WZ, Dyck PJ, van den Berg LH, Kiernan MC, Taylor BV, Taylor BV. Multifocal motor neuropathy: controversies and priorities. J Neurol Neurosurg Psychiatry. 2020; 91(2):140-148.

7. Vlam L, Cats EA, Harschnitz O, et al. Complement activity is associated with disease severity in multifocal motor neuropathy. Neurol Neuroimmunol Neuroinflamm. 2015; 2(4):e119.

8. Harschnitz O, van den Berg LH, Johansen LE, et al. Autoantibody pathogenicity in a multifocal motor neuropathy induced pluripotent stem cell-derived model. Ann Neurol. 2016;80(1):71-88.

9. van der Pol WL, Cats EA, van den Berg LH. Intravenous immunoglobulin treatment in multifocal motor neuropathy. J Clin Immunol. 2010;30(suppl 1):S79-S83.

10. Al-Zuhairy A, Jakobsen J, Andersen H, Sindrup SH, Markvardsen LK. Randomized trial of facilitated subcutaneous immunoglobulin in multifocal motor neuropathy. Eur J Neurol. 2019;26(10):1289-e82.

11. Herraets I, van Rosmalen M, Bos J, et al. Clinical outcomes in multifocal motor neuropathy: a combined cross-sectional and follow-up study. Neurology. 2020;95(14): e1979-e1987.

12. Lucisano Valim YM, Lachmann PJ. The effect of antibody isotype and antigenic epitope density on the complement-fixing activity of immune complexes: a systematic study using chimaeric anti-NIP antibodies with human fc regions. Clin Exp Immunol. 1991;84(1):1-8.

13. Dalakas MC, Alexopoulos H, Spaeth PJ. Complement in neurological disorders and emerging complement-targeted therapeutics. Nat Rev Neurol. 2020;16(11):601-617.

14. Van den Berg-Vos RM, Franssen H, Wokke JH, Van Es HW, Van den Berg LH. Multifocal motor neuropathy: diagnostic criteria that predict the response to immunoglobulin treatment. Ann Neurol. 2000;48(6):919-926.

15. Piepers S, Jansen MD, Cats EA, van Sorge NM, van den Berg LH, van der Pol WL. IVIg inhibits classical pathway activity and anti-GM1 IgM-mediated complement deposition in MMN. J Neuroimmunol. 2010;229(1-2):256-262.

16. Van de Walle I, Silence K, Budding K, et al. ARGX-117, a therapeutic complement inhibiting antibody targeting C2. J Allergy Clin Immunol. 2021;147(4):1420-1429.e7.

17. Ormel PR, Vieira de Sá R, van Bodegraven EJ, et al. Microglia innately develop within cerebral organoids. Nat Commun. 2018;9(1):4167.

18. Dimos JT, Rodolfa KT, Niakan KK, et al. Induced pluripotent stem cells generated from patients with ALS can be differentiated into motor neurons. Science. 2008; 321(5893):1218-1221.

19. Amoroso MW, Croft GF, Williams DJ, et al. Accelerated high-yield generation of limbinnervating motor neurons from human stem cells. J Neurosci. 2013;33(2):574-586.
20. Kim DD, Song WC. Membrane complement regulatory proteins. Clin Immunol. 2006; 118(2-3):127-136.

21. Cats EA, van der Pol WL, Tio-Gillen AP, Diekstra FP, van den Berg LH, Jacobs BC. Clonality of anti-GM1 IgM antibodies in multifocal motor neuropathy and the Guillain-Barré syndrome. J Neurol Neurosurg Psychiatry. 2015;86(5):502-504.

22. McMullen ME, Hart ML, Walsh MC, Buras J, Takahashi K, Stahl GL. Mannosebinding lectin binds IgM to activate the lectin complement pathway in vitro and in vivo. Immunobiology. 2006;211(10):759-766.

23. Vedeler C, Ulvestad E, Bjørge L, et al. The expression of CD59 in normal human nervous tissue. Immunology. 1994;82(4):542-547.

24. de Jonge RR, Vreijling JP, Meintjes A, et al. Transcriptional profile of the human peripheral nervous system by serial analysis of gene expression. Genomics. 2003;82(2): 97-108.

25. Koski CL, Estep AE, Sawant-Mane S, Shin ML, Highbarger L, Hansch GM. Complement regulatory molecules on human myelin and glial cells: differential expression affects the deposition of activated complement proteins. J Neurochem. 1996;66(1): 303-312.

26. van Beek J, van Meurs M, 't Hart BA, et al. Decay-accelerating factor (CD55) is expressed by neurons in response to chronic but not acute autoimmune central nervous system inflammation associated with complement activation. J Immunol. 2005; 174(4):2353-2365.

27. Nataf S, Stahel PF, Davoust N, Barnum SR. Complement anaphylatoxin receptors on neurons: new tricks for old receptors? Trends Neurosci. 1999;22(9):397-402.

28. Davoust N, Jones J, Stahel PF, Ames RS, Barnum SR. Receptor for the C3a anaphylatoxin is expressed by neurons and glial cells. Glia. 1999;26(3):201-211.

29. Dimitriadou MM, Alexopoulos H, Akrivou S, Gola E, Dalakas MC. Anti-neuronal antibodies within the IVIg preparations: importance in clinical practice. Neurotherapeutics. 2020;17(1):235-242.

30. Cats EA, Jacobs BC, Yuki N, et al. Multifocal motor neuropathy: association of anti-GM1 IgM antibodies with clinical features. Neurology. 2010;75(22): 1961-1967.

31. Laursen IA, Blou L, Sullivan JS, Bang P, Balstrup F, Houen G. Development, manufacturing and characterization of a highly purified, liquid immunoglobulin $\mathrm{G}$ preparation from human plasma. Transfus Med Hemother. 2014;41(3):205-212.

32. Arumugam TV, Tang SC, Lathia JD, et al. Intravenous immunoglobulin (IVIG) protects the brain against experimental stroke by preventing complement-mediated neuronal cell death. Proc Natl Acad Sci U S A. 2007;104(35):14104-14109.

33. Basta M, Van Goor F, Luccioli S, et al. F(ab)'2-mediated neutralization of C3a and C5a anaphylatoxins: a novel effector function of immunoglobulins. Nat Med. 2003; 9(4):431-438.

34. Basta M, Dalakas MC. High-dose intravenous immunoglobulin exerts its beneficial effect in patients with dermatomyositis by blocking endomysial deposition of activated complement fragments. J Clin Invest. 1994;94(5):1729-1735.

35. Fitzpatrick AM, Mann CA, Barry S, Brennan K, Overell JR, Willison HJ. An open label clinical trial of complement inhibition in multifocal motor neuropathy. J Peripher Nerv Syst. 2011;16(2):84-91.

36. Tedesco F. Inherited complement deficiencies and bacterial infections. Vaccine. 2008; 26(suppl 8):I3-I8.

37. Macedo AC, Isaac L. Systemic lupus erythematosus and deficiencies of early components of the complement classical pathway. Front Immunol. 2016;7:55. 


\section{Neurology \\ Neuroimmunology \& Neuroinflammation}

\section{Anti-C2 Antibody ARGX-117 Inhibits Complement in a Disease Model for Multifocal Motor Neuropathy \\ Kevin Budding, Lill Eva Johansen, Inge Van de Walle, et al. \\ Neurol Neuroimmunol Neuroinflamm 2022;9; \\ DOI 10.1212/NXI.0000000000001107}

This information is current as of November 10, 2021

\section{Updated Information \& \\ Services}

References

Subspecialty Collections

Permissions \& Licensing

Reprints including high resolution figures, can be found at: http://nn.neurology.org/content/9/1/e1107.full.html

This article cites 37 articles, 7 of which you can access for free at: http://nn.neurology.org/content/9/1/e1107.full.html\#\#ref-list-1

This article, along with others on similar topics, appears in the following collection(s):

All Immunology

http://nn.neurology.org//cgi/collection/all_immunology

All Neuromuscular Disease

http://nn.neurology.org//cgi/collection/all_neuromuscular_disease

Information about reproducing this article in parts (figures,tables) or in its entirety can be found online at:

http://nn.neurology.org/misc/about.xhtml\#permissions

Information about ordering reprints can be found online: http://nn.neurology.org/misc/addir.xhtml\#reprintsus

Neurol Neuroimmunol Neuroinflamm is an official journal of the American Academy of Neurology.

Published since April 2014, it is an open-access, online-only, continuous publication journal. Copyright

Copyright $\odot 2021$ The Author(s). Published by Wolters Kluwer Health, Inc. on behalf of the American

Academy of Neurology.. All rights reserved. Online ISSN: 2332-7812.

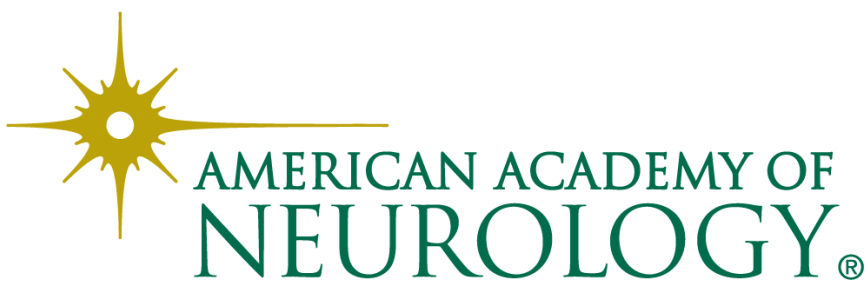

